\title{
PENGEMBANGAN KOMPETENSI PENDIDIK PAUD MELALUI DIKLAT KOMPETENSI SOSIAL
}

\author{
Anik Lestariningrum ${ }^{1}$, Intan Prastihastari W. ${ }^{2}$, Veny Iswantiningtyas ${ }^{3}$, Dema Yulianto ${ }^{4}$, \\ Nur Lailiyah ${ }^{5}$, Kuntjojo ${ }^{6}$ \\ 1,2,3,4,6 Program Studi Pendidikan Guru PAUD, ${ }^{5}$ Program Studi Pendidikan Bahasa dan Sastra \\ Indonesia, Fakultas Keguruan dan Ilmu Pendidikan \\ Universitas Nusantara PGRI Kediri \\ Email: anikl@unp.ac.id, aniklestariningrum@gmail.com
}

\begin{abstract}
The objectives to be achieved through this activity are developing the competence of PAUD educators especially their social competencies. This is done in relation to the amount of input from PAUD educators who have difficulties in dealing with the work environment, communicating with colleagues as well as student guardians regarding the presence of PAUD educators who are considered young and have just graduated. The method that will be used in this activity is in the form of training, where participants will be provided with knowledge and learn to practice indicators that hold on to social competence. The training was held for 2 days, this was intended to enable participants to absorb knowledge and implement indicators of social competence through direct practice and independent assignments. Training results were analyzed by questionnaire showing very effective results of 3003, effective 2310, ineffective 1617, and very ineffective 924. Based on the results of the questionnaire calculation the total value was 3212 so it can be said that the implementation of training was very effective. In addition, there were many participants who wrote their suggestions and hopes so that the educator's competency training activities continued continuously.
\end{abstract}

Keywords: social competence training, education educator

\begin{abstract}
Abstrak. Tujuan yang akan dicapai melalui kegiatan ini yaitu mengembangkan kompetensi pendidik PAUD khususnya kompetensi sosialnya. Hal ini dilakukan terkait banyaknya masukan dari pendidik PAUD yang mengalami kesulitanm dalam hal berhubungan dengan lingkungan kerja, berkomunikasi dengan sejawat juga dengan wali murid terkait adanya pendidik PAUD yang dianggap masih muda dan baru lulus sarjana. Metode yang akan digunakan dalam kegiatan ini berupa diklat dimana peserta akan dibekali pengetahuan dan belajar mempraktekan indikator yang ada berpegangan dengan kompetensi sosial. Diklat ini dilaksanakan selama 2 hari, hal ini dimaksudkan agar peserta mampu menyerap pengetahuan dan mengimplementasikan indikator kompetensi sosial melalui praktek langsung serta tugas mandiri. Hasil diklat dianalisis dengan angket menunjukkan hasil sangat efektif 3003, efektif 2310, tidak efektif 1617, dan sangat tidak efektif 924. Berdasarkan hasil penghitungan angket nilai total sebesar 3212 sehingga dapat dikatakan bahwa pelaksanaan diklat sangat efektif. Selain itu banyaknya peserta yang menuliskan saran serta harapannya supaya kegiatan diklat kompetensi pendidik terus dilakukan secara kontinyu.
\end{abstract}

Kata kunci : diklat kompetensi sosial, pendidik paud

\section{PENDAHULUAN}

Menjadi seorang pendidik khususnya anak usia dini harus memiliki kompetensi sesuai dengan pendidik pada umumnya pada tingkat pendidikan lainya. 4 kompetensi pendidik yaitu pedagogik, kepribadian, sosial dan professional. Keempat kompetensi tersebut harus dikuasai secara seimbang dan terus ditingkatkan dengan mengikuti berbagai kegiatan peningkatan kompetensi pendidik. Menurut Suyanto, (dalam Cristianti, 2012;113) menyatakan bahwa PAUD sebaiknya menjadi pendidik professional.

Menurut Catron dan Allen, (dalam Febrialismanto, 2017) menyatakan tulisan yang menyatakan bahwa seorang pendidik di anak usia dini bukan sekedar memberikan ilmu pengetahuan tetapi sebagai mentor serta fasilitator yang mengedepankan pola komunikasi yang positif kepada anak sehingga anak mampu menyesuaikan dimanapun dirinya berada.

Perkembangan ilmu dan pengetahuan menuju profesionalitas sesuai bidang masingmasing. Hubungan dalam lingkungan pendidik juga menjadi salah satu pendukung tercapainya profesionalitas pendidik. Bagaimana pendidik bisa diterima di semua kalangan sosial, mengelola hubungan kemasyarakatan juga memerlukan keterampilan yang harus terus 
dilatih. Konteks pentingnya keterampilan tersebut akan dipelajari dalam ranah kompetensi sosial.

Berdasarkan hasil penelitian

Cristianti,(2012;116) menyebutkan konsep

kompetensi sosial yaitu sebuah kemampuan dimana guru akan diharapkan beradaptasi dengan lingkungan serta berkomunikasi positif dengan anak dan orang tua murid. Implementasi kompetensi ini dapat dilihat saat pendidik menyesuaikan diri bergaul dengan rekan sejawat, tertib aturan di lembaga tempatnya mengabdi, penyesuaian dengan lingkungan masyarakat sekitar, berkomunikasi efektif mudah dipahami orang lain.

Sedangkan konsep kompetensi social yang dimuat dalam Peraturan Pemerintah No.19 Tahun 2005 tentang Standar Nasional Pendidikan mengemukakan pengertian tentang kompetensi social yang diharapkan dikuasai oleh pendidik adalah kemampuan pendidik sebagai bagian masyarakat untuk; (a) kemampuan berkomunikasi verbal, non verbal, (b) mampu menerapkan teknologi komunikasi dan informasi secara fungsional, (c) bergaul dengan baik pada anak didik, sesama tenaga pendidik dan kependidikan, orang tua murid, (d) kemampuan bergaul secara sopan santun di masyarakat tempat sekitarnya.

Ketika pendidik mengembangkan kompetensi atau keterampilan sosial pada peserta didiknya dapat menggunakan berbagai model pembelajaran salah satunya adalah bagaimana "modeling". Loh, (dalam Sit, 2012) konsep bermain dalam mengembangkan modeling tersebut tentunya dapat dikembangkan pendidik sebagai dasar bahwa seorang pendidik harus memberikan tauladan yang baik kepada peserta didiknya oleh karena itu penting penguasaan keterampilan sosial dalam dirinya.

Berdasarkan hasil observasi dari wawancara bersama pendidik PAUD ada beberapa masalah yang dihadapi oleh mereka terkait kompetensi social. Penggalian informasi awal ini diperoleh dari tugas mandiri yang dibuat oleh peserta diklat. Adapun masalah-masalah tersebut perlu mendapatkan pemecahan berkaitan pentingnya kompetensi social dikuasai dengan baik karena ketika kompetensi ini tidak diimplementasikan dengan baik akan mengganggu pencapaian kompetensi lainya. Masalah yang dituliskan oleh peserta diklat antara lain; (1) kurang menghargai rekan sejawat yang masih muda karena dianggap belum berpengalaman, (2) sikap kurang bisa berkomunikasi dengan baik pada wali murid saat menceritakan perkembangan anak didik, (3) kurang percaya diri saat dimasyarakat diminta menjadi salah satu orang diberi tugas, (4) kurang bersikap sopan antara pendidik dan atasan.

Berdasarkan permasalahan ini dirancang sebuah diklat pengembangan kompetensi pendidik melalui diklat kompetensi social supaya nantinya pendidik PAUD yang menjadi peserta nantinya akan memiliki kemampuan untuk berkomunikasi serta bergaul secara efektif dengan anak didik, rekan sejawat pendidik dan tenaga kependidikan, orang tua murid dan masyarakat di lingkungan sekitar. Diklat ini nantinya akan dirancang dalam bentuk ceramah, praktik langsung serta tugas mandiri supaya hasil yang dicapai optimal.

\section{METODE PELAKSANAAN}

Metode yang akan digunakan metode kuantitatif dan kualitatif melalui teknik analisis deskriptif. Dimana metode kuantitatif akan digunakan dalam mengolah data hasil diklat melalui pengisian angket peserta sedangkan analisis deskriptif akan mendeskripsikan hasil data kuantitatif.

Pelaksanaan kegiatan selama 2 hari yaitu 9-10 Maret 2019 bertempat di gedung A5 kampus I Universitas Nusantara PGRI Kediri. Diklat akan diikuti oleh 50 orang peserta alumi S1 PG-PAUD UN PGRI Kediri, 10 orang pengurus serta 5 mahasiswa HIMA PAUD yang membantu dalam pelaksanaan.

Metode pendekatan akan dilaksanakan supaya tercapai tujuan kegiatan pengabdian adalah sebagai berikut:

1. Persiapan dilakukan pertama dengan koordinasi tim pengabdian (Dosen PG-PAUD) bersama pengurus Alumi serta mahasiswa

2. Melakukan koordinasi dengan Warek I terkait perijinan tempat gedung A5

3. Menyusun pembagian materi tim, tanggungjawab dan tugas-masing-masing juga tupoksi pengurus dan mahasiswa supaya pelaksanaan dapat berjalan dengan lancar 
4. Kegiatan diklat yaitu "Pengembangan Kompetensi Pendidik PAUD Melalui Diklat Kompetensi Sosial "peserta khusus alumi PG-PAUD, FKIP, Universitas Nusantara PGRI Kediri.

5. Membuat daftar online dengan dibatasi peserta hanya berjumlah 50 orang dilakukan oleh admin

prodi yang membatu terkait regristrasi peserta

Berdasarkan urutan berbagai rancangan metode perencanaan tersebut diharapkan nantinya pelaksanaan kegiatan berjalan dengan lancar dan juga mencapai hasil yang optimal

\section{HASIL DAN PEMBAHASAN}

Untuk mencapai hasil tentunya tahapan akhir dari sebuah pengabdian masyarakat adalah bagaimana ketercapaian keberhasilan program tersebut dan manfaatnya terhadap masyarakat yang menjadi peserta. Adapun paparan hasil pelaksanaan program dapat dijabarkan seperti dibawah ini:
1) Kegiatan koordinasi awal dengan melalui rapat dengan tim pengabdian, tim pengurus dan juga mahasiswa yang membantu. Dapat dilihat pada foto di bawah ini

2)Pelaksanaan Kegiatan pemateri menyampaikan sesuai materi masing-masing kemudian berfoto bersama Dekan dan peserta. Dapat dilihat dari foto dokumentasi pada Gambar 1, 2 \&3.

Hasil yang diperoleh menunjukan secara keseluruhan berjalan dengan baik bahkan dengan hasil angket yang diolah diperoleh hasil Karena nilai total sebesar 3212 sehingga dapat dikatakan bahwa pelaksanaan diklat sangat efektif. Hasil keefektifan itu melalui penghitungan dengan SPPS secara kuantitatif dengan menghitung secara keseluruhan dimana dapat ditunjukan pada tabel 1 sebagai berikut:
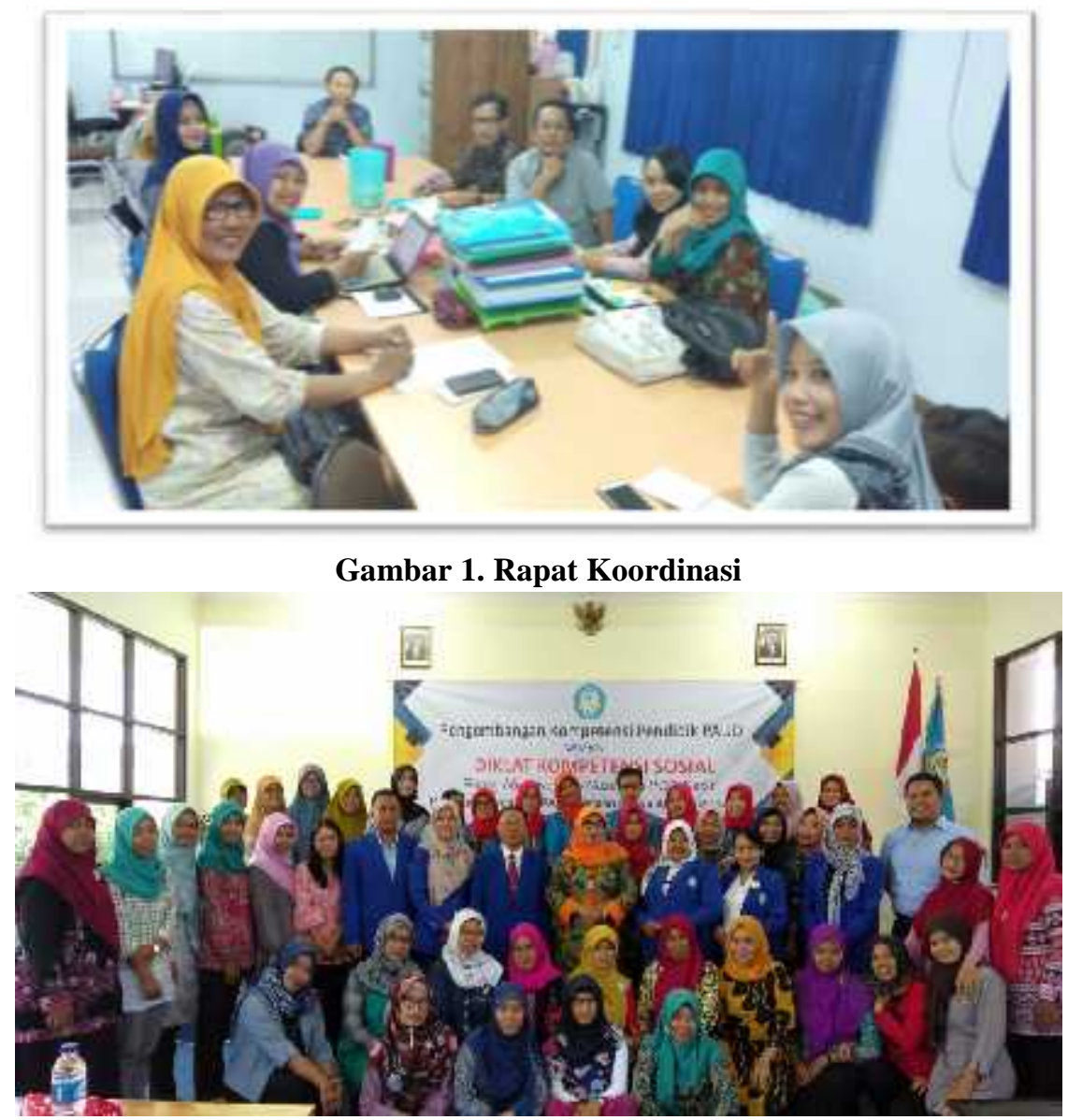

Gambar 2. Foto Bersama Seluruh Peserta dengan Dekan 


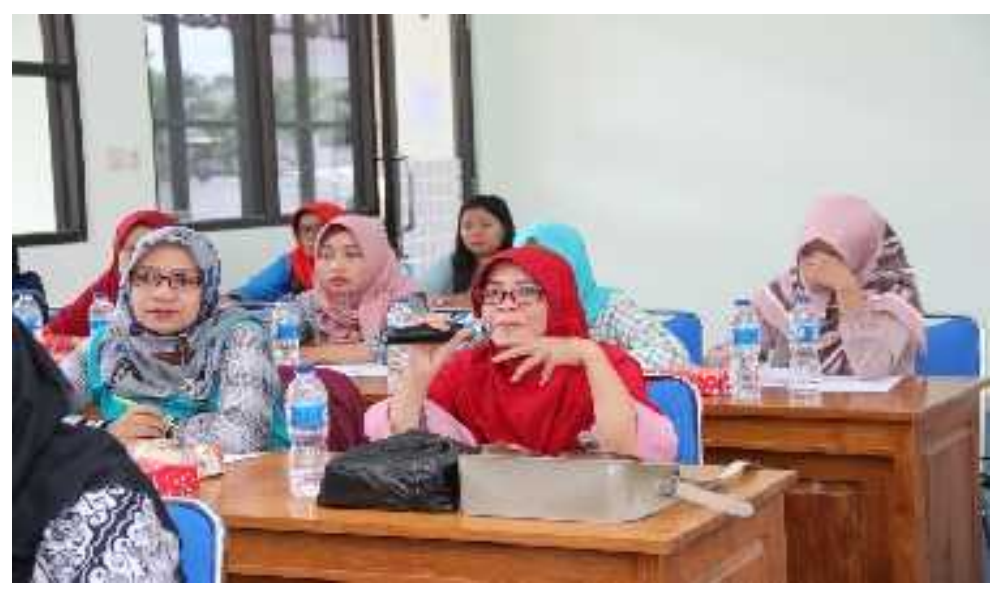

Gambar 3. Peserta Mengajukan Pertanyaan

Tabel 1. Analisis Hasil Angket Kepuasan Kegiatan Diklat

KESELURUHAN

\begin{tabular}{lll} 
& IK MAKS & $\mathbf{3 6 9 6}$ \\
& IK MIN & $\mathbf{9 2 4}$ \\
I & $\mathbf{6 9 3}$ \\
\hline Sangat efektif & 3003 & 3696 \\
\hline Efektif & 2310 & 3003 \\
\hline Tidak efektif & 1617 & 2310 \\
\hline Sangat tidak efektif & 924 & 1617 \\
\hline
\end{tabular}

Berdasarkan tabel 1 di atas secara dana kegiatan dengan bantuan stimulus yayasan kuantitatif juga diperoleh hasil apa yang sudah yang dikeluarkan melalui lembaga penelitian dilakukan dari rancangan kegiatan diklat universitas dan tim pengabdian yaitu prodi PGmencapai hasil memuaskan. Selain itu adanya PAUD atas kerjasamanya dalam menjalankan kolom masukan yang diisi oleh peserta rata-rata peserta menyarankan untuk dapat diadakan kegiatan seperti ini tentunya dengan biaya terjangkau, kualitas bagus karena dikemas dalam kegiatan yang tidak membosankan dan ilmu yang diperoleh sesuai kebutuhan peserta.

\section{SIMPULAN DAN SARAN}

Kegiatan pengabdian yang dilakukan dalam bentuk diklat selama 2 hari ini dapat meningkatkan keterampilan sosial para pendidik PAUD sebagai peserta yang terlibat langsung selama kegiatan dari awal sampai akhir dan memeroleh keilmuan tentang konsep keterampilan sosial dan prantek beragam kompetensi sosial yang harus dilakukan sebagai pendidik khususnya di PAUD sebagai salah satu kompetensi yang harus dicapai untuk menjadi pendidik yang profesional di bidangnya.

\section{UCAPAN TERIMA KASIH}

Penulis mengucapkan terima kasih Kepada YPLPT PGRI Kediri selaku penyandang

\section{DAFTAR PUSTAKA}

Cristianti, M. 2012. Profesionalisme Pendidik AUD. Jurnal Pendidikan Anak, Vol.1, Edisi 1, Juni, 2012

Febrialismanto. 2017. Analissi Kompetensi Profesional Guru PG-PAUD Kabupaten Kampar Provinsi Riau, Volume. 6, Edisi. 2 Desember 2017

Salinan PP No. 19 Tahun 2005. Standart Nasional Pendidikan

Sit. Masganti, 2012. Peningkatan Kompetensi Sosial Anak Usia Dini Dengan Metode Bermain Peran (Studi Kasus di Raudhatul Athfal Muhajirin-Medan). Jurnal Pendidikan dan Kebudayaan, Vol. 18, Nomor 1, Maret 2012. 